\title{
LINGUA GALEGA: ENTRE A IDENTIDADE E A MUNDIALIZACIÓN Rosario Álvarez
}

Consello da Cultura Galega, Instituto da Lingua Galega, Universidade de Santiago de Compostela doi:10.17075/tucmeg.2015.002 

O título deste capítulo pode parecer un tanto pretensioso, pois son moitos e variados os ámbitos científicos e foros de alto debate intelectual que nos últimos tempos se teñen ocupado deste tema ou de temas conexos. Non debe esperarse desta contribución nin unha síntese crítica do novo coñecemento adiantado nos estudos neste dominio nin, moito menos, unha achega teórica orixinal ou innovadora a propósito dun tema tan complexo e multifacético. Preténdese só colocar o tema no campo de atención da comunidade investigadora e de persoas interesadas nos estudos galegos, por considerar que é o ámbito idóneo para reflexionarmos sobre a posición e posible proxección internacional (interlingüística) do galego e para nos preguntarmos sobre as estratexias e opcións de futuro.

Pertencemos a un pobo moi dado á reflexión e conversa sobre a lingua, tanto dándolle voltas ao código coma á súa situación social, de modo que moitas das ideas que seguen (con estas ou outras palabras), forman parte de comentarios habituais entre persoas galegas que non son lingüistas. Con frecuencia atopámonos en situacións problemáticas que nos parecen exclusivas de nós, pola nosa particular situación sociolingüística; contribúe a iso a propaganda centralista das linguas oficiais de estados poderosos, que promoven idearios a favor do monolingüismo e da exclusión da diferenza.

Así, foinos transmitido que a situación lingüística ideal é a dunha sociedade monolingüe e botamos a vida perseguindo a volta a unha situación sociolingüística coma a que presuntamente tiveron os nosos devanceiros medievais (exclusión feita da concorrencia do latín e da presenza en distintas doses doutras variedades románicas, que tiveron despois maior ou menor fortuna). Para unha grande parte dos e das defensoras dunha liña monolingüística pouco importa que a maior parte da comunidade científica poña sobre a mesa, unha e outra vez e en todo o mundo, o feito incontestable de que a realidade mostra teimosamente que a «normalidade» - entendida como o común ou usual — está do lado das sociedades bilingües ou plurilingües.

Tamén se ten discutido, e moito, sobre a dificultade de vida normalizada (e incluso pervivencia) das linguas con ámbito territorial reducido. Estas 
CAstro, O. / M. LiÑEIRA (eds.) (2015): Trama e urda. Contribucións multidisciplinares desde os estudos galegos, Santiago de Compostela, Consello da Cultura Galega. doi:10.17075/tucmeg.2015.

dificultades (na prensa, na literatura, na ciencia, nos negocios, etc.) resultan maiores se estas linguas non teñen estado. De feito, incluso no seo da mesma comunidade hai grupos que discuten a conveniencia da aprendizaxe e uso da lingua propia, medíndoa en termos de rendibilidade no contexto planetario. Esquécese (ou preténdese que se esqueza) que todas as linguas son ferramentas de comunicación válidas en función das circunstancias, entre as que non ocupa un lugar menor o medio; isto é, unha lingua pode ser a única idónea no seo da comunidade e inadecuada para unha relación internacional concreta. Aínda en relación co anterior, tense alertado do perigo de que a lingua identitaria se enquiste no seu espazo territorial ou simbólico, sexa porque os seus e súas falantes a abandonan fóra del, sexa porque non dá captado o interese dos e das falantes doutra lingua ou de estudosos do estranxeiro.

Neste contexto, propómonos analizar a posición do galego no universo das linguas e mais a presenza da lingua galega no mundo, no territorio que non lle é propio por nacenza, a través de galegofalantes que residen fóra da terra, de estranxeiros e estranxeiras que a incorporaron ao seu fardel, e finalmente do seu ensino como lingua estranxeira.

\section{UNHA NOVA ORDE LINGÜÍSTICA}

A globalización produce unha nova orde lingüística caracterizada en gran parte, pero non só, pola emerxencia dunha lingua particular, o inglés, que se vai convertendo na lingua global, supranacional e supraestatal, impulsada non só polas instancias de poder instaladas en poderosos países anglófonos, senón moi activamente polos gobernos e elites dirixentes de países que teñen unha ou máis linguas propias, distintas do inglés e nos máis dos casos distanciadas del en tipoloxía. Impulsado por un movemento planetario e con esas axudas endóxenas e esóxenas, o inglés non só se foi convertendo na lingua de relación internacional no mundo dos negocios, da política, das comunicacións, da investigación, etc., senón, en moitos lugares, na lingua de instalación das clases sociais altas e de boa parte da mocidade. Non hai máis que ver a enorme cantidade de recursos, públicos e privados, destinados á aprendizaxe do inglés, á tradución simultánea e á versión de obras orixinais a esta lingua (incluso de textos que nunca chegan a ver a luz na primeira versión). Chega un punto en que na valoración do seu coñecemento se inverten os papeis: saber inglés deixou de ser un mérito para ser un requisito; non falar inglés convértese nunha eiva e, desde 
CAstro, O. / M. LIÑEIRA (eds.) (2015): Trama e urda. Contribucións multidisciplinares desde os estudos galegos, Santiago de Compostela, Consello da Cultura Galega. doi:10.17075/tucmeg.2015.

logo, nun factor de exclusión. Houbera xa outras linguas imperiais expandidas polo mundo con funcións de intercomunicación semellantes, pero en toda a historia da humanidade nunca unha proporción semellante de poboación, en circunstancias e lugares tan diversos, abandonara ou complementara a lingua propia para adoptar (con maior ou menor destreza e grao de corrección) unha mesma lingua diferente.

O movemento a favor do inglés semella hoxe imparable, se ben ningún lingüista se atreverá a negar que a longo ou medio prazo se pode conter e mesmo reverter, porque a historia é pendular e porque a hexemonía (económica, cultural, política, relixiosa, militar...) nunca é para sempre. En todo caso, no presente, obsérvanse xa algúns indicios de resistencia activa ou de reacción contra esa tendencia á mundialización do inglés como lingua $\mathrm{A}$, entre os que cómpre destacar catro:

a) Débense considerar nesta liña os movementos «ecolingüísticos», de forma moi ampla e non só referidos á «ameaza» do inglés. A ecolingüistica ou ecoloxía lingüistica pode ser comprendida e definida de distintas maneiras. Aos efectos que nos interesan, destacamos a póla da lingüística que ten como obxectivo principal detectar situacións de fraxilidade do medio e risco de extinción, para fomentar políticas que defendan o equilibro e a conservación da diversidade lingüística, contribuíndo así á preservación e protección das linguas do mundo.

b) En reacción máis directa ao exclusivo predominio do inglés, debemos considerar o movemento englobable baixo o rótulo intercomprensión (románica, xermánica, etc.), que con frecuencia crecente é unha actitude sostida a nivel individual ou por pequenos grupos, mais no que se enmarcan organizacións multinacionais como Unión Latina ou Festlatino, e proxectos articulados como EuroComRom, EuroComGerm e EuroComSlav. Así se expresa a páxina que dá a benvida a EuroCom (o subliñado é noso): ${ }^{1}$

- Na casa europea, as linguas non son alleas unhas para as outras, están relacionadas.

- No seo das familias lingüísticas románica, eslava e xermánica a xente enténdese naturalmente.

- EuroCom traza o camiño cara ao plurilingüismo.

- A intercomprensión europea constitúe a nivel cultural un complemento ao inglés como lingua universal.

- EuroCom preserva a riqueza cultural e lingüística de Europa.

\footnotetext{
${ }^{1}$ Véxase http://www.eurocom-frankfurt.de
} 
CAStro, O. / M. LiÑEIRA (eds.) (2015): Trama e urda. Contribucións multidisciplinares desde os estudos galegos, Santiago de Compostela, Consello da Cultura Galega. doi:10.17075/tucmeg.2015.

A novidade destes movementos reside en que toman a bandeira do interlingüismo como garantía do respecto e preservación da diversidade cultural e lingüística, sen converter ningunha das linguas particulares en hexemónica («por unha latinidade plural», proclama por exemplo a Unión Latina). ${ }^{2}$ A alianza estratéxica dos falantes de linguas románicas doadamente intercomprensibles, e por tanto dominables a efectos prácticos (decodificación oral e/ou escrita), converte esta forza humana nunha das máis numerosas e espalladas por todo o mundo. ${ }^{3}$ De por parte, estas linguas están en contacto con numerosísimas linguas indíxenas, das que son interlocutoras privilexiadas.

c) O temor de que a globalización resulte en «homoxeneización» acentúa os movementos identitarios e de defensa de todos os espazos simbólicos que garanten a individualidade de pobos, entre eles en primeiro lugar a lingua. Como nos fai notar Fishman (2001: 4), nunca ata hoxe houbera tantas linguas estandarizadas nin con políticas de recuperación en marcha, en número que crece significativamente co paso do tempo. Prográmanse accións de política lingüística, non só aplicables a linguas minorizadas emerxentes (caso do galego), senón tamén a linguas que ata agora non se sentiran ameazadas (caso do francés); así, a lei Toubon de 1994 xorde como reacción fronte á ameaza do inglés (limitación e substitución canónica de anglicismos, obriga de usar o francés na publicidade escrita e audiovisual, etc.).

d) Algúns autores salientan claros indicios dunha tendencia global de regreso ás orixes, que pode supoñer unha oportunidade para linguas vinculadas a herdanzas familiares ou históricas, por exemplo ao portugués na China, India e nos territorios lusófonos de África (David Graddol, apud FLAD 2008: $28-33^{4}$ ). A oportunidade aumenta consonte $o$ fai a

\footnotetext{
${ }^{2}$ Véxase http://www.unilat.org/SG/es

3 Ocorre incluso no seo de cada lingua, orientando conxuntamente a política lingüística oficial consonte o principio pluricéntrico, o que implica que o centro orixinario abandone o concepto patrimonialista da «autenticidade». Así se declara formalmente na política oficial das academias da lingua española, cando optan polo «panhispanismo», o que obriga á Real Academia Española a cambiar a súa perspectiva e a esforzarse por asumir que deixa de ser a única institución con capacidade para se pronunciar sobre a norma en toda a área descontinua de lingua española. Parte das reticencias portuguesas sobre o Acordo ortográfico explícanse pola dificultade de asumir unha posición semellante desde Portugal; desde Brasil, voces autorizadas, defensoras de actitudes e propostas integradoras, sosteñen que a lusofonía, para ser viable, debe ser «entendida de maneira ampla e abrangente, multicêntrica e heterogênea» (Faraco 2010: $81)$.

4 Nesta liña, os autores do informe A Internacionalização da Língua Portuguesa. Para uma política articulada de promoção e difusão, que teñen á vista un complexo estramado de datos e criterios, presentes e cara ao futuro, propoñen valorizar «os pontos de ancoragem» que deixou no Oriente a historia da presenza portuguesa, sobre todo na India, Xapón e Macau (e, a través deste enclave, na China), do mesmo xeito que chaman a atención sobre as especificidades do escenario africano, decorrentes de circunstancias históricas recentes (aínda que, precisamente por isto, alertan de que nalgúns casos será
} 
CAstro, O. / M. LiÑEIRA (eds.) (2015): Trama e urda. Contribucións multidisciplinares desde os estudos galegos, Santiago de Compostela, Consello da Cultura Galega. doi:10.17075/tucmeg.2015.

consideración do inglés como unha «destreza básica», adquirida desde niveis cada vez máis baixos, pois o lugar «lingua estranxeira», presente en todos os sistemas educativos, xa pode ser ocupado por un abano maior de linguas cunha opción real, entre elas as que se vinculan á herdanza cultural.

\section{A FORTALEZA E VALORES ESTRATÉXICOS DAS LINGUAS}

É un lugar común afirmar que a vitalidade dunha lingua non se mide polo número de falantes senón pola robustez que mostra dentro do seu territorio, no seu nicho. Poderiamos engadir que ese vizo é independente da maior ou menor necesidade que sintan os seus e súas falantes, individual ou colectivamente, de coñeceren outra ou outras linguas non propias. Acórdansenos exemplos coñecidos, non moi distantes: unha lingua coma o danés móstrase vital no seu territorio, a pesar de ser unha lingua moderadamente areal (isto é, circunscrita a un territorio de non grandes dimensións con algunhas extensións a países contiguos) ${ }^{5}$ e de andar por preto de 5,5 millóns de falantes. O mesmo ocorre co islandés, lingua rexional, que anda preto do cuarto de millón (Moreno 2003: 150), se ben este pequeno número explica que as súas e seus falantes aprendan maioritariamente outras linguas alleas (de forma obrigada polo ensino, inglés e danés). Por desgraza, non podemos dicir que esta sexa a situación do galego; por iso nos atopamos nun proceso de «normalización», isto é, de recuperación desa vitalidade interna ata atinxir un grao satisfactorio no seo da sociedade galega. Mais non é o noso propósito presente ocuparnos deste tipo de vitalidade, dentro da comunidade de falantes. Lembraremos só que a Carta europea das linguas rexionais e minoritarias, ratificada polo Consello de Europa en 1992, se dirixe á protección destas linguas como expresión da riqueza cultural, buscando a súa revitalización mediante o emprego en novos ámbitos, que abarcan todos os sectores da vida pública (educación, administración, xustiza, medios de comunicación, vida económica...), mais sempre dentro do territorio que lles é propio en cada caso; dito doutro xeito, a Carta só se pronuncia sobre a vitalidade interna.

preciso lidar cautelosamente con contas pendentes e resentimentos aínda non resoltos, que poderían actuar en sentido contrario ao desexado) (Reis 2010: 22-23).

${ }^{5}$ Galicia ten unha extensión de $29.574 \mathrm{~km}^{2}$, fronte aos $43.098 \mathrm{~km}^{2}$ de Dinamarca. O danés é a lingua oficial de Dinamarca (5.535.000 habitantes), é cooficial en Groenlandia e as Illas Feroe, e é moi coñecida como segunda ou terceira lingua en Islandia. Conta en total con 5,3 millóns de persoas falantes, segundo Moreno (2003: 150). 
CAStro, O. / M. LiÑEIRA (eds.) (2015): Trama e urda. Contribucións multidisciplinares desde os estudos galegos, Santiago de Compostela, Consello da Cultura Galega. doi:10.17075/tucmeg.2015.

Outra dimensión é o valor estratéxico das linguas, que se mide sobre todo fóra do territorio e da propia comunidade de falantes, en interacción con outras comunidades humanas e con outras linguas: ben polas oportunidades que a lingua propia ofrece aos seus naturais fóra do país de procedencia ou do nicho adquirido (a resposta á recorrente pregunta «para que quero o galego fóra de Galicia?»), ben polo recoñecemento que lle demostran falantes doutras linguas (volvendo a unha pregunta típica, «por que unha persoa estranxeira vai querer aprender galego?»). Ese valor estratéxico é importante porque está en relación directa co valor económico e co poder que cada lingua ten: enténdasenos ben, non falamos en termos de dominio, senón de difusión e dunha fortaleza disuasoria ante os intentos de asoballamento. O valor estratéxico está, adoito, detrás da elección lingüística que fan os individuos cando se lles presenta a ocasión ou obriga de optar: en que lingua quero instalarme, facer literatura, redactar un artigo científico, rodar un filme, facer a publicidade, poñer un anuncio, rotular a miña empresa, educar as miñas crianzas; e, tamén, que outras linguas quero aprender e dominar plenamente, en cales me gustaría poder ler ou ver un filme en versión orixinal, etc.

$\mathrm{Na}$ definición deste valor estratéxico xoga un complexo sistema de variables, que se combinan en distintos graos. ${ }^{6}$ Interveñen factores coma os seguintes:

a) O número, dimensión, posición e espallamento dos países en que se fala (como primeira lingua ou non). É unha lingua rexional, coma o islandés con 250.000 falantes (Moreno 2003: 150) ou coma o bengalí, unha das dez máis faladas do mundo con 170 millóns (Moreno 2003: 243)? É unha lingua expandida, como primeira ou segunda lingua, nunha rexión xeográfica internacional, relativamente pequena (coma o danés) ou relativamente ampla (coma o alemán)? É unha lingua que se estende por vastas rexións do planeta, continuas (caso do árabe e ruso) ou descontinuas (caso do francés, español e portugués)?

b) A relación como lingua areal coas linguas rexionais ou locais, sobre todo nos casos en que as linguas vernáculas sexan especialmente abundantes e diferentes entre si. O francés non é unha das dez linguas máis faladas do mundo, pero si unha das máis estendidas; máis alá do seu valor como lingua oficial dunha das potencias europeas (e algúns territorios

\footnotetext{
${ }^{6}$ Como xa foi indicado, a Carta europea das linguas pouco achega a este respecto. Limítase a (a) facer unha declaración leve sobre a necesidade de fomentar o entendemento mutuo entre todos os grupos lingüísticos dun país, e a (b) esixir que se promovan activamente os intercambios transfronteirizos no caso de linguas que se falen noutros estados (como lingua minoritaria ou maioritaria).
} 
CAstro, O. / M. LiÑEIRA (eds.) (2015): Trama e urda. Contribucións multidisciplinares desde os estudos galegos, Santiago de Compostela, Consello da Cultura Galega. doi:10.17075/tucmeg.2015.

limítrofes), do Québec, dalgúns países caribeños e polinésicos, etc., o francés ten un importante valor estratéxico como lingua de comunicación en diversos países de África, derivado da colonización francesa e belga, especialmente na zona subsahariana. A pesar dunha secular política lingüicida, en Brasil fálanse arredor de 200 linguas indíxenas, de extensión e número de falantes desiguais, dunhas 20 familias distintas, algunhas de grupos xenéticos moi diferenciados: a intercomunicación ten que facerse a través de individuos bilingües, en xeral a través do portugués, polo que esta lingua cobra unha grande importancia estratéxica en toda a área.

c) A proximidade tipolóxica con outra ou outras linguas, o que facilita a intercomprensión entre elas. Nese sentido, dentro da familia xermánica, pódese afirmar que o valor estratéxico do islandés é menor có do danés, porque este é facilmente comprensible polos falantes das outras dúas linguas nórdicas continentais (sueco e o noruegués [bokmål]), coas que feito forma un continuum lingüístico. Voltando á Península Ibérica, a singularidade do éuscaro é un factor de illamento en contra, que non teñen o catalán ou o galego.

d) A medida en que falantes alleas/os deciden aprendela como lingua de intercomunicación, polo xeral en actividades que non atinguen toda a poboación senón segmentos máis ou menos especializados. En última instancia, «a globalización referida á comunicación lingüística ten que ver cos procesos en que unhas linguas se usan cada vez máis na comunicación internacional mentres que outras perden importancia e incluso desaparecen» (Garrido 2010: 71). Segundo o British Council, no ano 2000 aprendían inglés como lingua estranxeira entre 750 e mil millóns de persoas en todo o mundo; segundo o Instituto Cervantes, en 2010 aprendían español como segunda lingua 14 millóns de persoas, un terzo en Europa e dous terzos en América (datos tomados de Garrido 2010: 88-89): a distancia entre o interese mostrado no dominio dunha e outra linguas repercute no diferente valor estratéxico. 
CAstro, O. / M. LiÑEIRA (eds.) (2015): Trama e urda. Contribucións multidisciplinares desde os estudos galegos, Santiago de Compostela, Consello da Cultura Galega. doi:10.17075/tucmeg.2015.

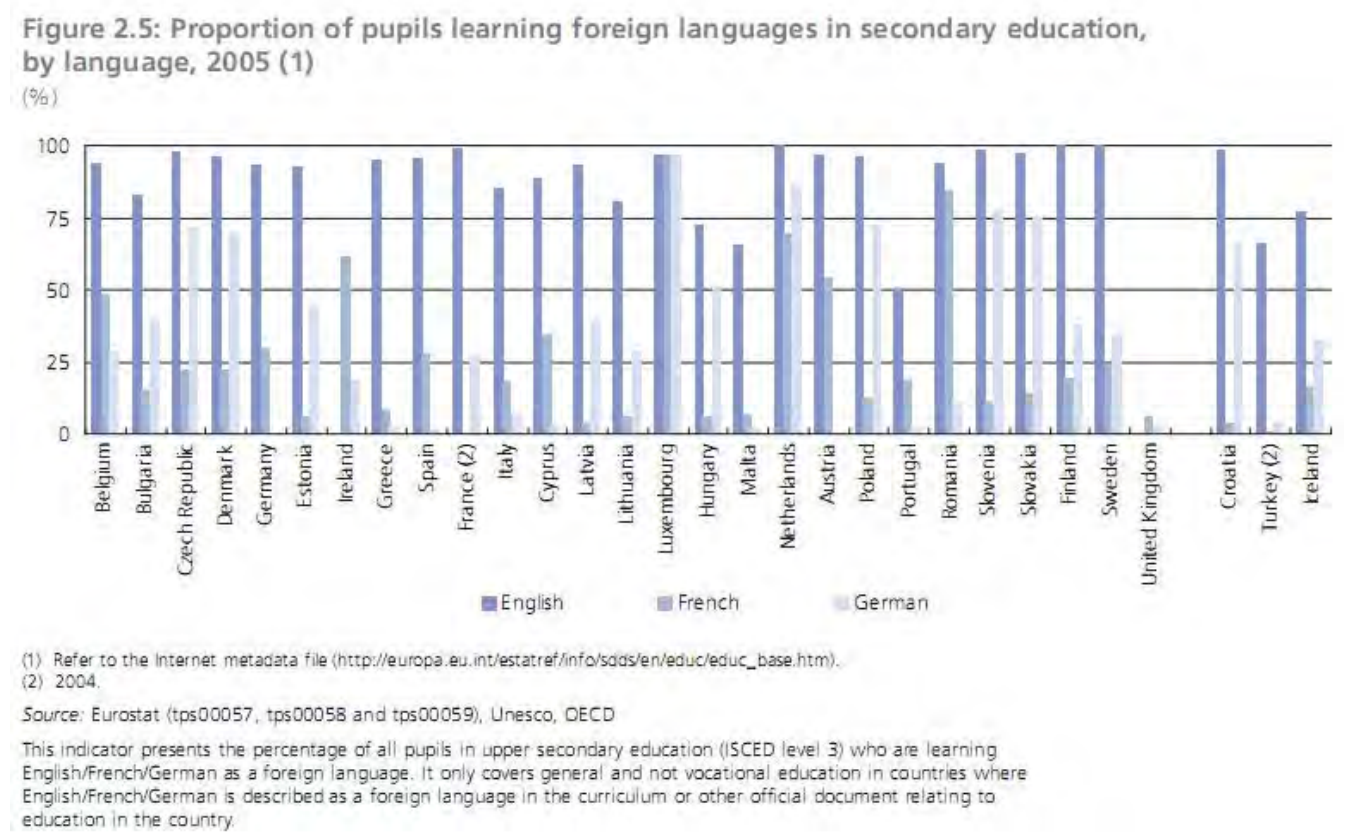

Fig.1 Aprendizaxe de linguas estranxeiras en Europa (datos de 2005, Eurostat)

Os datos do gráfico anterior proceden do Anuario 2005 de Eurostat e refírense á Unión Europea, Croacia, Turquía e Islandia. ${ }^{7}$ Repárese no seguinte: ao parecer, a poboación en idade escolar do Reino Unido non ten necesidade de aprender linguas estranxeiras; en todos os países de lingua non-inglesa, a lingua preferente é o inglés (salvo Bélxica, por razóns doadamente comprensibles); na Europa occidental, a segunda lingua é o francés; na Europa central e oriental como segunda opción domina amplamente o alemán, coa excepción moi marcada de Romanía. Só se consideran tres linguas, porque as outras non teñen datos significativos neste nivel académico; dito doutro xeito, os responsables do sistema educativo ou os estudantes en condicións de elixir non recoñecen valor estratéxico ao italiano, portugués, español... Por darmos un dato máis abranguente, fóra do ensino secundario, apuntamos que, segundo o Eurobarómetro 2012, as cinco linguas estranxeiras máis faladas na UE - no sentido de ter competencias para manter unha conversa noutra lingua - son, por esta orde, o inglés (38\%), francés (12\%), alemán (11\%), español $(7 \%)$ e ruso $(5 \%){ }^{8}$

7 Dispoñible en http://epp.eurostat.ec.europa.eu. No último Anuario, con datos de 2009 e nalgúns casos 2008, falta información fundamental en varios países membros, polo que tomamos como referencia o anterior.

8 Houbo cambios signiticativos desde o Eurobarómetro 2006: mantense o inglés (38\%), descenden francés e alemán (tiñan 14\%) e mais o ruso (antes 6\%), só aumenta o español (antes 6\%). Sen dúbida, isto garda relación co aumento do valor estratéxico do español, pois na última enquisa as linguas que a cidadanía percibe como máis útiles son, despois do inglés, 
e) A vinculación coa innovación e a tecnoloxía. Parece incuestionable que este factor pode explicar que no contexto europeo se vexa como mellor investimento aprender francés ou alemán antes ca español ou portugués. É evidente que Internet deu un enorme pulo ao inglés e non faltaron voces que alertaron sobre o posible monolingüismo imposto pola rede. Co paso do tempo, a realidade mostrouse diferente: a medida que se foi difundindo e xeneralizando o acceso a esta rede e aos seus recursos, o peso específico do inglés foi diminuíndo. Así, no ano 2000 cerca do 50\% dos usuarios de Internet tiñan o inglés como primeira lingua; en 2007 a porcentaxe baixara ao 29\% (Graddol, apud FLAD, 2008: 31).

Por iso algúns autores (De Swaan 1993 e 2001; Calvet 2004) falan da «galaxia das linguas», organizadas nun sistema gravitacional en que unhas gravitan no campo doutras, non necesariamente nunha relación de dependencia senón de subsistencia e, en moitos casos, de apoio mutuo. Nese universo, as linguas clasifícanse pola posición que ocupan e pola rede de relacións que son capaces de establecer coas restantes, próximas ou afastadas. Sintetizando as propostas máis recorrentes, establecemos cinco chanzos (de límites difusos):

a) Lingua local: circunscrita a un pequeno territorio sen autonomía política nin administrativa, como por exemplo o mirandés.

b) Lingua rexional: circunscrita ao seu dominio básico, sexa este un pequeno estado (caso do islandés) ou unha nación sen estado (casos do galego, catalán, bengalí...). Entran tamén neste grupo as linguas de pobos instalados nunha área xeográfica que non se corresponde cos límites de ningún estado (por exemplo, o aimará, estendido no altiplano entre Bolivia, Chile e Perú, e en parte da Arxentina).

c) Lingua areal: lingua dun estado ou nación con extensións, como primeira ou segunda lingua, nunha área de influencia próxima (danés, sueco, croata); con frecuencia, por razóns xeopolíticas, superponse a linguas autóctonas (caso do hindi).

d) Lingua internacional: lingua de varios estados ou nacións, en distribución areal continua (árabe, ruso, alemán...) ou policéntrica (francés, español, portugués...).

e) Lingua global: lingua internacional con capacidade para superpoñerse a todas as anteriores, cando menos en determinados grupos sociais e en determinados usos globais (de momento, só o inglés). 
CAstro, O. / M. LIÑEIRA (eds.) (2015): Trama e urda. Contribucións multidisciplinares desde os estudos galegos, Santiago de Compostela, Consello da Cultura Galega. doi:10.17075/tucmeg.2015.

\section{A POSICIÓN E VALOR ESTRATÉXICOS DO GALEGO}

De acordo coa exposición anterior, no concerto mundial o galego é unha lingua rexional, circunscrita ao seu dominio básico. Na nosa opinión, o feito de que o galego se fale fóra dos límites administrativos de Galicia non resta validez á afirmación básica de que se trata dunha lingua rexional, xa que eses territorios contiguos son tamén constitutivos. De todos os xeitos, tendo en conta que as decisións sobre a lingua nos territorios estremeiros dependen doutras administracións e que a comunidade de falantes, fragmentada por razóns sociopolíticas, gravita arredor de distintos centros de poder, podería considerarse moderadamente areal.

O número de falantes habituais estímase preto de 3 millóns no territorio orixinario (Galicia e banda occidental de Asturias, León e Zamora), ao que se suman as e os falantes que a teñen como segunda lingua. Ademais, debido a procesos migratorios recorrentes a moitas e diversas partes do mundo, existe unha ampla comunidade galega no exterior, que con frecuencia se articulou en sociedades e conservou a súa lingua como marca de identidade e vehículo comunicativo no ámbito privado e, nalgunhas áreas, tamén no público (publicacións periódicas, creación e edición literaria, comunicación radiofónica, artes escénicas e música...). Probablemente a suma de todo sexa o que xustifica a atribución de «algo menos de cuatro millones de hablantes localizados en su mayoría en Galicia» (Moreno 2003: 199); Ethnologue, que lle atribúe algo máis de 3 millóns, sitúa o galego no posto 160 das linguas do mundo. No ámbito europeo é unha lingua de tamaño medio-baixo, lonxe das cifras das 17 máis faladas (por riba de 10 millóns de falantes) e no intermedio das que se contan por millóns; nesa orde, sitúase entre outras linguas con estado, como o noruegués (4 millóns) e o lituano (3 millóns), dun lado, e o letón, macedonio e o esloveno (2 millóns) do outro (naturalmente, como xa foi dito, a similitude queda nas cifras, pois estas non son por si determinantes da fortaleza e status). Segundo información sintetizada pola Real Academia Galega, «por número de falantes o galego ocupa o lugar 160 entre as 5.500 linguas do mundo, o lugar 23 entre as 150 linguas europeas e é a segunda lingua europea máis falada entre as non oficiais en ningún estado»».

O galego é lingua propia e oficial dunha nación sen estado, como se recolle no Estatuto de Autonomía de Galicia, que tamén contempla a

\footnotetext{
${ }^{9}$ Estes e outros datos básicos están dispoñibles en: http://www.realacademiagalega.org/datos-uso
} 
CAstro, O. / M. LiÑEIRA (eds.) (2015): Trama e urda. Contribucións multidisciplinares desde os estudos galegos, Santiago de Compostela, Consello da Cultura Galega. doi:10.17075/tucmeg.2015.

oficialidade do español, en canto que lingua oficial de toda España $;{ }^{10}$ de por parte, o galego, xunto co vasco e o catalán, son as tres únicas linguas europeas non oficiais de estados que poden ser utilizadas nas institucións da Unión Europea. Este carácter de semioficialidade, desde 2005, recoñece o dereito de nos poder dirixir por escrito en galego ás institucións comunitarias e a ser respondidos na mesma lingua, e mais propicia que algúns documentos e publicacións oficiais sexan traducidos ao galego. ${ }^{11}$

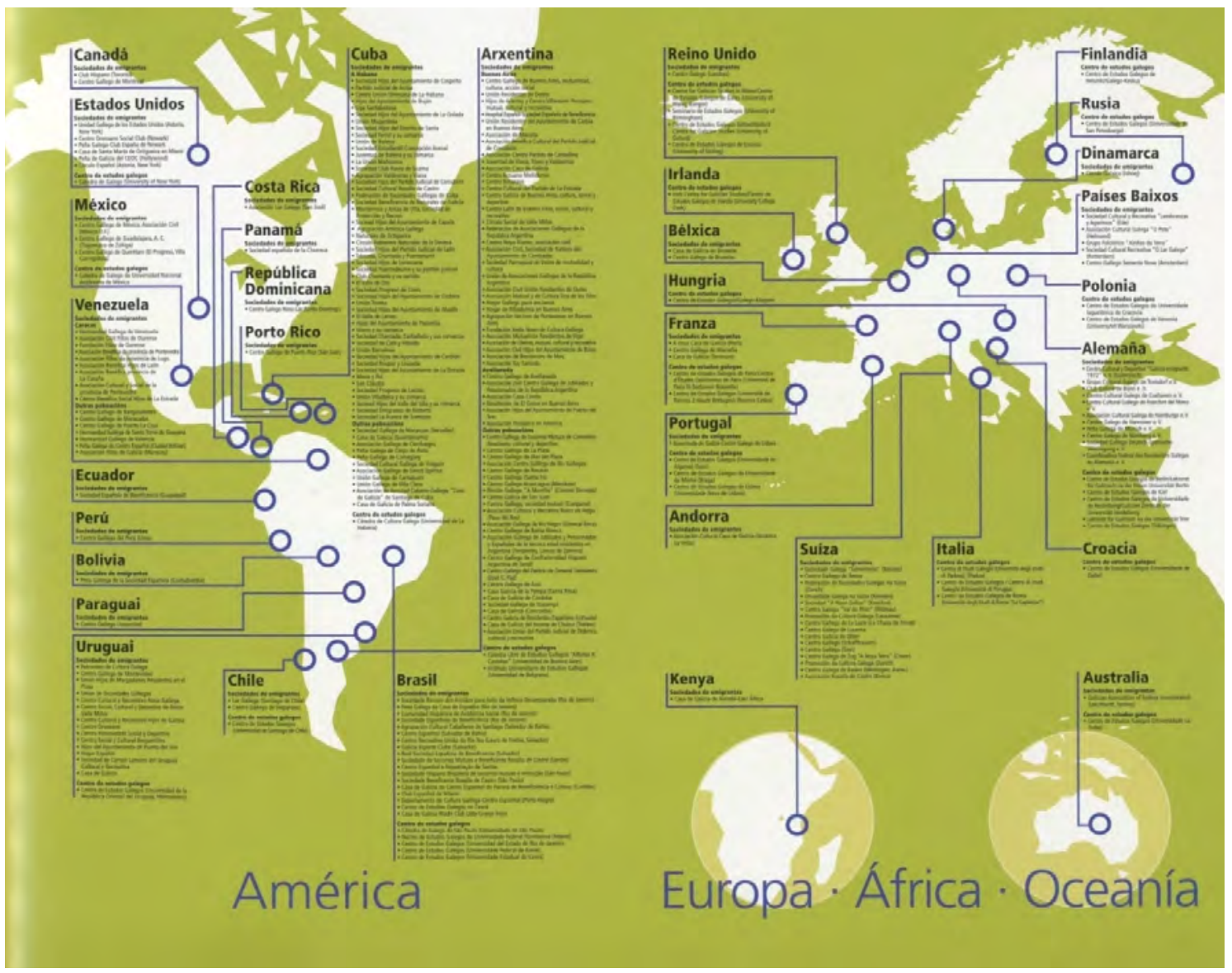

Fig. 2. Galicia no mundo. Sociedades de emigrantes e centros de estudos galegos. Fonte: $\mathrm{CCG}$

\footnotetext{
${ }^{10}$ Segundo recolle o Estatuto de Autonomía de Galicia, no artigo 5 «1.A lingua propia de Galicia é o galego. | 2. Os idiomas galego e castelán son oficiais en Galicia e todos teñen o dereito de os coñecer e de os usar. 3. Os poderes públicos de Galicia garantirán o uso normal e oficial dos dous idiomas e potenciarán o emprego do galego en tódolos planos da vida pública, cultural e informativa, e disporán os medios necesarios para facilita-lo seu coñecemento. |4. Ninguén poderá ser discriminado por causa da lingua.»

${ }^{11}$ Para máis información, véxase: http://www.xunta.es/linguagalega/o_galego_na_union_europea
} 
CAstro, O. / M. LiÑEIRA (eds.) (2015): Trama e urda. Contribucións multidisciplinares desde os estudos galegos, Santiago de Compostela, Consello da Cultura Galega. doi:10.17075/tucmeg.2015.

O galego é a lingua propia de Galicia, berce dunha comunidade espallada polo mundo. Sexa pola emigración (antiga e moderna), sexa polo exilio, Galicia ten esta característica singular de gran potencialidade estratéxica. Conta cunha rede de centos de centros e organizacións constituídos desde hai moitos anos polas colectividades da emigración, que en boa medida deberían ser repensados para os adaptar ás necesidades da sociedade actual e garantir a pervivencia. Conta agora con novas e novos emigrantes, con moita máis cualificación, que están presentes en empresas sobranceiras e institucións decisorias, desde Bruxelas ou Londres ata Nova York ou Shangai; os novos núcleos de emigrantes cualificadas/os poden ser o fermento sobre o que construír as antenas de Galicia ao longo de todo o mundo. O mapa recollido na fig. 2, elaborado polo Consello da Cultura Galega (CCG) para a exposición «Galicia 25. Unha cultura para un novo século», ${ }^{12}$ aproxima de forma sintética e plástica a rede de institucións galegas no mundo, nacidas na súa maior parte da comunidade, da sociedade civil. Un patrimonio singular, unha rede planetaria, que pode servir de canle excepcional á lingua galega. Esta é tamén a nosa forza, se sabemos reorientala e aproveitala.

Galicia ten tamén outras características culturais salientables. A cultura, como marca-país, é o aspecto que nos define positivamente e reflicte unha identidade propia, orixinal e por iso única, con características e estilo propios que consolidan unha reputación e un recoñecemento de Galicia a partir deses trazos positivos e singulares. Naturalmente, nesa imaxe cultural vai a lingua, a literatura, a gastronomía, a ciencia, a industria, a artesanía, a paisaxe, etc. Entre os trazos singulares está a nosa posición de finis terrae, a meta dese Camiño de Santiago que vertebra Europa, que durante séculos colocou Galicia no mapa mental de millóns de persoas europeas, e que é amais carta de presentación positiva aos ollos de millóns de persoas de todo o mundo. A lingua e a cultura de Galicia poden beneficiarse desta rede e dos factores de prestixio que van ligados a ela.

A lingua galega intégrase nun espazo de continuum románico, dentro do bloque hispánico occidental, basicamente galego-portugués. A estreita similitude co portugués, que nos coloca de forma natural no seu mesmo bloque lingüístico, é un activo que engade un gran valor estratéxico ao galego, xa que esa é unha das dez linguas máis faladas do planeta en número de falantes nativos (a sétima, segundo algunhas estimacións, só por detrás do chinés mandarín, inglés, español, árabe, bengalí e hindi). A intercomprensión lingüística antes aludida está garantida entre falantes de

${ }^{12}$ Catálogo da exposición dispoñible en: http://consellodacultura.gal/mediateca/extras/galicia25anos.pdf 
CAstro, O. / M. LiÑEIRA (eds.) (2015): Trama e urda. Contribucións multidisciplinares desde os estudos galegos, Santiago de Compostela, Consello da Cultura Galega. doi:10.17075/tucmeg.2015.

galego e de portugués, con graos diversos dependendo, sobre todo, das distintas variedades orais dentro da lusofonía. Chamamos a atención, ademais, sobre o feito da contigüidade territorial con Portugal como un factor positivo que sumar nesa posición estratéxica. Este é un activo que a lingua galega ten e que a comunidade de falantes non explota adecuadamente; para facelo, debería fomentar a consciencia deste valor e desta oportunidade, valorando o coñecemento do portugués (máis alá da simple decodificación) e procurando o intercambio transfronteirizo.

Dentro do espazo iberorrománico, o continuum prolóngase polo leste. Entre o galego e o asturiano ou o castelán hai tamén unha gran similitude (menor cá que teñen galego e portugués, pero alta e significativa en todo caso); ademais, hoxe todas as persoas galegofalantes dominan en maior ou menor grao o español, oral e escrito. Esa proximidade ao español (que na planificación do corpus tendemos a ver como un perigo asimilacionista) amplía a xa mencionada intercomprensión románica; e faino a través doutra lingua internacional que, por descontinua, está entre as máis faladas e estendidas do planeta. ${ }^{13}$

Por tanto, pódese afirmar que o galego, alicerce fundamental da marca Galicia, ten o valor estratéxico de ser a lingua propia dunha comunidade lingüística que é ponte entre os dous hemisferios do hispanismo, o nucleado polo español e o nucleado polo portugués. Segundo as diferentes estimacións de número de falantes, a suma de falantes nativas/os de español e portugués duplica a cifra de falantes nativas/os de inglés, e sitúase por riba de $3: 4$ se consideramos o número de falantes. $\mathrm{O}$ coñecemento e uso do galego permite a intercomprensión con ese vasto mundo lingüístico e cultural.

A pesar do dito anteriormente, a proxección exterior do galego, que se podería estear nese carácter de ponte e na dispersión da galeguidade por todo o mundo, é moi feble. É consecuencia de que en Galicia, respecto do status da lingua, sempre existiu maior preocupación pola normalización no seu interior ca pola presenza e difusión fóra das nosas fronteiras; e isto a pesar de que o galeguismo cultural do século XX se caracterizou pola apertura e vontade de se inserir nun contexto europeo, sen o reducionismo localista. As propostas e accións políticas tamén estiveron sempre dirixidas, fundamentalmente, ao artellamento e normalización internas.

${ }^{13}$ Cómpre insistir na aclaración de que non estamos a falar de medidas de planificación do corpus, no sentido de achegamento ou distanciamento normativo respecto de español ou portugués, senón de posición estratéxica e de distancia, sendo o galego como é, sen necesidade de transformarse naquilo que non é. 
CAstro, O. / M. LiÑEIRA (eds.) (2015): Trama e urda. Contribucións multidisciplinares desde os estudos galegos, Santiago de Compostela, Consello da Cultura Galega. doi:10.17075/tucmeg.2015.

Pero esta consideración e recoñecemento da nosa febleza neste ámbito non nos debe ocultar que non faltaron accións nestoutro sentido: pénsese nas promovidas por comunidades galegas emigrantes (emisións radiofónicas, representacións teatrais, prensa periódica, edicións literarias...) e, nun nivel máis académico, na penetración en universidades estranxeiras de galeguistas emigrantes ou exiliados/as ou na creación da Asociación Internacional de Estudos Galegos (AIEG). A novidade dos últimos tempos é que hai iniciativas que perseguen en liñas xerais este obxectivo. A programación é feble e mellorable, como veremos; nun casos parte de instancias públicas (gobernamentais) e noutros semellan iniciativas particulares (empresas da cultura, grupos de investigación, etc.). Pódense considerar nesta liña: (a) a tradución de obras literarias dalgúns dos nosos autores e autoras máis representativas a outras linguas; (b) os cursos de lingua e cultura galegas para persoas estranxeiras; (c) os cursos de lingua e cultura galegas para a comunidade galega emigrante; (d) a creación de lectorados e Centros de Estudos Galegos en universidades fóra do Sistema Universitario de Galicia; e (e) a cooperación científica entre grupos de investigación sediados en Galicia e persoal investigador (individuos, equipos, grupos, institutos...) en centros de investigación en diversos lugares do mundo.

As novas tecnoloxías e a rede global reveláronse como unha oportunidade extraordinaria para proxectar a cultura e difundir a lingua galega no exterior, non como a ameaza que vaticinaban outrora as voces agoireiras. Sen dúbida a presenza do galego na Internet é aínda bastante limitada, con soporte fragmentario cando non escaso, como diagnostican as autoras do Libro branco sobre o galego na era dixital (García / Arza 2012: 14, 33-34). Isto non lles impide ser «moderadamente optimistas», porque no tecido investigador galego existen o dinamismo, competencia e interese necesarios. A propia existencia deste libro branco marca un camiño: forma parte dunha serie destinada a avaliar $o$ apoio das tecnoloxías da linguaxe en 30 linguas europeas, pois ao identificar as carencias, necesidades e deficiencias, poderase «deseñar un programa de investigación e desenvolvemento a grande escala dirixido á construción dunha Europa verdadeiramente plurilingüe e tecnoloxicamente avanzada» (Ib.: 31). O valor estratéxico do galego aumenta e refórzase na medida en que interacciona coas outras linguas oficiais europeas nestes ámbitos.

En distintos lugares recollemos a afirmación de que o galego se encontra entre as 30 linguas máis usadas na Internet no mundo, por diante de linguas que o triplican ou quintuplican en número de falantes; non a facemos nosa, porque ignoramos a orixe e fundamento desa aseveración, 
CAstro, O. / M. LiÑEIRA (eds.) (2015): Trama e urda. Contribucións multidisciplinares desde os estudos galegos, Santiago de Compostela, Consello da Cultura Galega. doi:10.17075/tucmeg.2015.

así como os datos que serven de base a un cálculo obxectivo. Ora ben, un experto como Gómez Guinovart (2003: 4), ao medir o tamaño da web en lingua galega a partir do número de páxinas por lingua indexadas en Allthewe, podía afirmar hai algo máis dunha década que «o galego aparece no posto trixésimo sétimo, con 98.998 páxinas e o 0’014\% das páxinas da arañeira, inmediatamente seguido polo euskara (0’011\%)».

\section{A POLÍTICA LINGÜÍSTICA NO EXTERIOR}

Ao analizarmos con algún detalle as características da promoción cultural galega no exterior atopamos unha acción esmigallada, que non obedece nin a unha estratexia de país nin a unha ou varias programacións minimamente coordinadas; nin sequera a promoción da lingua está encarreirada, a pesar de pertencer sobre todo á Secretaría Xeral de Política Lingüística (SXPL). Segundo un informe elaborado polo Observatorio da Cultura Galega (dependente do CCG), a partir da análise dos presupostos 2011 da Comunidade Autónoma de Galicia, sobre as entidades públicas galegas que realizan promoción cultural no exterior, chégase a dúas conclusións básicas: (a) ningunha instancia gobernamental ten encomendada de maneira preferente esta tarefa; (b) non hai un fío condutor nin unha planificación coordenada, senón accións independentes que non garanten continuidade nin complementariedade. ${ }^{14}$ A falta dunha política definida de acción exterior e dunha instancia de planificación, xunto coa atomización de orzamentos e medidas, debilitan de forma preocupante a proxección exterior de Galicia, da súa cultura e da súa lingua. $\mathrm{Na}$ exposición sobre a proxección exterior da lingua galega imos centrarnos na aprendizaxe da lingua fóra de Galicia ou como lingua estranxeira dentro da comunidade.

\footnotetext{
${ }^{14}$ A relación de entidades que, segundo os presupostos de 2011, realizaron accións desde tipo no ámbito da Xunta de Galicia foron: a Secretaría Xeral de Emigración (baixo a Presidencia da Xunta de Galicia); a Fundación Galicia Europa e a Dirección Xeral de Relacións Exteriores e coa Unión Europea (Consellería de Presidencia, Administracións Públicas e Xustiza); a Dirección Xeral de Promoción e Difusión da Cultura, a Axencia Galega das Industrias Culturais (AGADIC) e a Sociedade Anónima de Xestión do Plan Xacobeo (Consellería de Cultura e Turismo); a Secretaría Xeral de Política Lingüística e o Centro Ramón Piñeiro para a Investigación en Humanidades (Consellería de Educación); a Agrupación Europea de Cooperación Territorial Galicia-Norte de Portugal; o Consorcio Audiovisual de Galicia e o Consorcio de Santiago.
} 
CAstro, O. / M. LiÑEIRA (eds.) (2015): Trama e urda. Contribucións multidisciplinares desde os estudos galegos, Santiago de Compostela, Consello da Cultura Galega. doi:10.17075/tucmeg.2015.

\subsection{O ensino do galego fóra de galicia: ámbito non universitario}

Unha das nosas grandes eivas é a falta de conexión entre as accións de atención á emigración (dun lado) e a proxección exterior do galego e a acción cultural (do outro). Se o comparamos cos modelos catalán e vasco, un dos obxectivos dos institutos Etxepare e Ramon Llull é precisamente o aproveitamento dos centros culturais e sociais na diáspora. No entanto, nun panorama de acción exterior descentralizada, parcial e descoordinada coma a galega, isto resulta francamente difícil. En consecuencia, apenas se ofrece a posibilidade de afondar no estudo da lingua familiar ao numeroso colectivo de emigrantes galegas e galegos e descendentes, privando a esta poboación da posibilidade de manteren o vínculo coa cultura das súas orixes e de reforzaren os trazos identitarios. A densa rede de Centros galegos e Casas de Galicia espalladas por todo o mundo constitúe aínda unha estrutura ampla e estable apropiada para acoller accións deste tipo; mesmo podería contribuír a darlles unha oportunidade de sobrevivencia, de superar a crise provocada polo cambio xeracional.

\subsubsection{Accións da Xunta para a comunidade residente no exterior}

A Lei de Normalización Lingüistica de 1983 afirma no seu preámbulo que a lingua é un dos factores da recuperación da identidade colectiva por ser o núcleo vital da nosa identidade. Ademais engade que a lingua é a maior e máis orixinal creación colectiva dos galegos, pois é a verdadeira forza espiritual que lle dá unidade interna á nosa comunidade; e, mais que na Galicia do presente serve de vínculo esencial entre a poboación galega afincada na terra nativa e a emigrada polo mundo. Recoñécese, por tanto, desde o preámbulo a necesidade de promover o galego no exterior para que as galegas e galegos da emigración poidan coñecer a nosa lingua; por iso, o título $\mathrm{V}$ desta lei está dedicado ao galego no exterior e di no seu artigo 21 que «o Goberno Galego fará uso dos recursos que lle confiren a Constitución Española e o Estatuto de Autonomía para que os emigrantes galegos poidan dispoñer de servizos culturais lingüísticos en lingua galega». Neste contexto encádranse as actividades culturais e cursos de galego na rede de centros galegos no exterior, que dependen de eventuais convocatorias conxuntas da SXPL e da Secretaría Xeral de Emigración. Consisten en cursos preparatorios de lingua galega, para os niveis CELGA, e de extensión cultural. $\mathrm{O}$ feito de non teren data fixa nin programación estable nin continuidade dificulta a planificación, tanto para os centros como para as posibles persoas interesadas. 
É difícil avaliar a eficacia e resultados destes cursos. En setembro de 2012, os datos máis actualizados que ofrece a Xunta de Galicia sobre este aspecto na súa páxina son do ano 2007 e na memoria da SXPL de 2010 nin se mencionan. Con todo, no DOG de 13/07/2011 aínda saíu a convocatoria, que alcanzaba ata finalizar o primeiro semestre de 2012. Os datos proporcionados para o ano 2007 só permiten achegarse ao reparto xeográfico e tipo de actividade: nas distintas comunidades españolas (Andalucía, Asturias, Castilla-León, Cataluña, País Vasco, Madrid) óptase por cursos de iniciación ou perfeccionamento da lingua, sen dúbida orientándose á obtención dos certificados acreditativos do seu coñecemento, requisito ou mérito para a consecución de determinados postos de traballo en Galicia. ${ }^{15} \mathrm{O}$ mesmo ocorre coa programación, escasa, da emigración europea (Alemaña, Francia, Suíza). En cambio, a emigración americana opta pola extensión cultural (Arxentina, Cuba). Segundo González González (2007: 391), na década que vai do ano 1995 ao 2005 impartíronse 868 cursos non regrados deste tipo, repartidos na maioría dos países de América e de Europa occidental. No seu traballo, que ofrece gráficos por anos, número de cursos e de alumnado (demostrando que a media anual de alumnado está por riba das dúas mil persoas, malia que se descoñeza cal é o número de persoas diferentes que se beneficiaron), González González conclúe que se dá «a circunstancia de que a eles acode unha porcentaxe cada vez máis alta de persoas non galegas interesadas pola lingua, a literatura e a cultura deste país».

\subsubsection{Accións do Instituto Cervantes}

Como afirmou Iñaki Anasagasti no seu blog en 2007, «el Instituto Cervantes tiene solo servicios mínimos en relación a las lenguas cooficiales». ${ }^{16}$ Mais é un espazo co que debemos contar, pois ao cabo está sostido con recursos públicos de toda a cidadanía, tamén dos que non nos recoñecemos como falantes naturais de español. E, de feito, na páxina da SXPL, baixo a epígrafe Outros cursos fóra de Galicia, afírmase que os centros do Instituto Cervantes nos diferentes continentes ofertan a posibilidade de estudar galego, cando existe unha demanda (aínda que, na práctica, na páxina do Cervantes non existe nin a opción de saber onde se programan nin como demandalos). En resposta á nosa petición de información en

\footnotetext{
${ }^{15}$ Dispoñible en: http://www.xunta.es/linguagalega/arquivos/cursos_exterior.pdf

${ }^{16}$ Dispoñible en: http://ianasagasti.blogs.com/mi_blog/2007/03/el_instituto_ce.html
} 
CAstro, O. / M. LiÑEIRA (eds.) (2015): Trama e urda. Contribucións multidisciplinares desde os estudos galegos, Santiago de Compostela, Consello da Cultura Galega. doi:10.17075/tucmeg.2015.

setembro de 2012, Álvaro García Santa-Cecilia, xefe do Departamento de Ordenación Académica do Instituto Cervantes respondeu en síntese: ${ }^{17}$

- No curso académico 2011-2012 ofreceuse a opción de cursos de galego no $55 \%$ dos centros ( 34 de 62 centros); podería ofertarse no $45 \%$ restante se houbese constancia de alumnado interesado. Que se ofreza non quere dicir que se imparta.

- A actividade docente de galego está concentrada no centro de París. Desde o curso 1996-1997 ata o 2010-2011 abriu polo menos un curso de galego cada ano académico, atendido polo lectorado de galego da Universidade París III Sorbonne Nouvelle. O alumnado é maioritariamente descendente de persoas galegas ou emigrantes xa na xubilación, pero tamén hai alumnado francés. No curso 2011-2012 non houbo alumnado.

- Só noutras dúas ocasións houbo cursos de galego noutros centros da rede do IC: en 2003-2004, en Múnic; en 2007-2008, en Bruxelas.

- A maioría dos cursos de lingua galega son de nivel básico A1, mais tamén se abriron algúns cursos especiais de perfeccionamento.

Ademais, no Espazo das Linguas Ibéricas, promovido en Madrid polo Instituto Cervantes xunto coa Universidade de Alcalá de Henares, hai cursos dirixidos á obtención do CELGA. ${ }^{18} \mathrm{O}$ ensino do catalán é responsabilidade do Institut Ramon Llull, o do éuscaro da Euskaltzaindia e o portugués do Instituto Camões. Cómpre salientar que o ensino do galego non depende da Real Academia Galega, que gardaría similitude co caso vasco, nin coas universidades, coas que a SXPL convenia para os cursos de verán, senón da Xunta de Galicia a través do seu Centro Ramón Piñeiro para a Investigación en Humanidades, un organismo que non ten actividades nin obxectivos docentes.

\subsubsection{No ensino primario e secundario fóra de Galicia}

A oferta neste ámbito é practicamente inexistente. Daremos só, como apuntamentos, noticia de iniciativas meritorias e programacións singulares.

A primeira delas é o Proxecto Galauda, unha iniciativa nacida na Universitat de Barcelona, coa colaboración das dúas administracións autonómicas da Xunta de Galicia e da Generalitat de Catalunya. ${ }^{19} \mathrm{O}$ proxecto busca a introdución do galego como segunda lingua moderna nos centros de ensino secundario, e a reciprocidade de ensino do catalán en

\footnotetext{
${ }^{17}$ Comunicación por correo electrónico.

${ }^{18}$ Dispoñible en: http://www.xunta.es/linguagalega/arquivos/CursosGalego2012-2013Calendario.pdf

${ }^{19}$ Para máis información, véxase: http://phobos.xtec.cat/galauda/
} 
CAstro, O. / M. LiÑEIRA (eds.) (2015): Trama e urda. Contribucións multidisciplinares desde os estudos galegos, Santiago de Compostela, Consello da Cultura Galega. doi:10.17075/tucmeg.2015.

Galicia. O equipo elabora materiais de aprendizaxe (Vencello, Galauda) e organiza, coa colaboración da SXPL, viaxes anuais coas alumnas e alumnos a Galicia. Catro institutos imparten a materia de galego optativa como segunda lingua moderna: IES Narcís Monturiol (Barcelona), IES Arquitecte Manuel Raspall (Cardedeu), IES Margarita Xirgu (L’Hospitalet de Llobregat), IES Sant Just Desvern (Sant Just Desvern).

A Xunta de Galicia mantén colaboración permanente cos centros Cañada Blanch de Londres (Reino Unido) e Santiago Apóstol de Buenos Aires (Arxentina), para garantir a oferta de aprendizaxe da lingua galega nestas dúas cidades. No colexio Santiago Apóstol estúdase galego en todos os cursos, desde a etapa preescolar ata o nivel secundario; en 2011-2012, o número de alumnado que estudaban galego neste centro era de 404, nun total de catorce grupos, que asistían ás materias de Lingua e Literatura, Xeografía e Historia de Galicia. No colexio Vicente Cañada Blanch de Londres ofréceselle clases de galego ao alumnado de primaria e secundaria. En Caracas (Venezuela), o colexio Castelao, da Irmandade Galega de Venezuela, imparte clases de lingua galega dentro do currículo escolar.

O ensino de galego nas áreas estremeiras está fóra da xurisdición das institucións públicas galegas. Existe unha colaboración permanente da Xunta de Galicia coa Junta de Castilla y León, mais non con Asturias. Na comunidade de Castilla y León - conforme ao artigo 4.2 do seu estatuto de autonomía verbo da protección para a lingua galega nos lugares nos que habitualmente se utiliza - a materia de lingua e cultura galegas está incorporada aos plans de estudo dos centros de ensino primario e secundario nas áreas galegófonas de León e Zamora; o ensino do galego está regulado pola ORDEN EDU/1190/2007, de 28 de xuño de $2007 .^{20}$

\subsubsection{Outras opcións}

Os cursos de lingua on-line están moi pouco desenvolvidos. Na páxina da SXPL, baixo o rótulo «autoaprendizaxe», hai unha relación exhaustiva que na súa brevidade revela por si mesma o atraso e o déficit neste campo.

En Escolas Oficiais de Idiomas de Madrid, Ponferrada e Barcelona impártense ensinanzas oficiais do idioma galego nos distintos niveis.

\footnotetext{
${ }^{20}$ Toda a información e acceso aos documentos en: http://www.xunta.es/linguagalega/castilla_y_leon
} 
CAstro, O. / M. LiÑEIRA (eds.) (2015): Trama e urda. Contribucións multidisciplinares desde os estudos galegos, Santiago de Compostela, Consello da Cultura Galega. doi:10.17075/tucmeg.2015.

\subsection{O ensino do galego como lingua estranxeira fóra de Galicia: ámbito universitario}

Para a difusión exterior do galego e a súa consideración como lingua de estudo é fundamental a presenza en universidades espalladas pola maior parte do mundo. Hoxe isto comeza a facerse real sobre todo a través dos lectorados e dos Centros de Estudos Galegos programados e subvencionados pola SXPL, pero é xusto recoñecer que tiveron ilustres e meritorios antecesores en épocas anteriores. Como nos lembra González González (2005: 4),

La docencia de la lengua gallega en las principales universidades del mundo es, por lo menos desde el punto de vista simbólico, fundamental para obtener un estatus de lengua reconocida internacionalmente. $\mathrm{Y}$, aunque existían loables precedentes de cursos de gallego en diversas universidades, como los impartidos en Moscú por la doctora Galina Zenenko, en Tubinga por E. Coseriu, en Pasau por Xosé Teixeira, en Friburgo por F. Domínguez Reboira, en Brown por A. Carreño, en Maine por Kathleen March, en Wisconsin por Alberto Moreiras o en Mississippi por Michael T. Qeyja, la iniciativa más importante en la introducción de la docencia de la lengua y cultura gallegas en el exterior ha sido sin duda la creación de los Centros de Estudos Galegos.

De acordo con datos publicados pola Xunta de Galicia, en setembro de 2012 hai 38 centros espallados por España (9) e outros 16 países, a maior parte europeos..$^{21}$ Comparando os datos actuais con outros aínda recentes, compróbase que houbo retrocesos nalgúns lugares, pois foron pechados centros que viñan funcionando, algúns de longa data. Así, desde a memoria de 2010 pecharon os centros de Murcia, Buenos Aires (Belgrano), La Habana, México e Montevideo; con anterioridade fixérano os de Trier, Rennes, Perugia, Santa Bárbara, Lisboa (UL), Stirling e Melbourne. O repaso dos nomes abonda para mostrar a dimensión enorme da perda, que se mide tamén no carácter simbólico que moitos deste lugares teñen para a cultura galega e na achega impagable que fixeron en décadas anteriores á promoción e difusión da lingua galega no mundo.

${ }^{21}$ Datos e contactos en http://www.xunta.es/linguagalega/lectorados_de_universidades. 


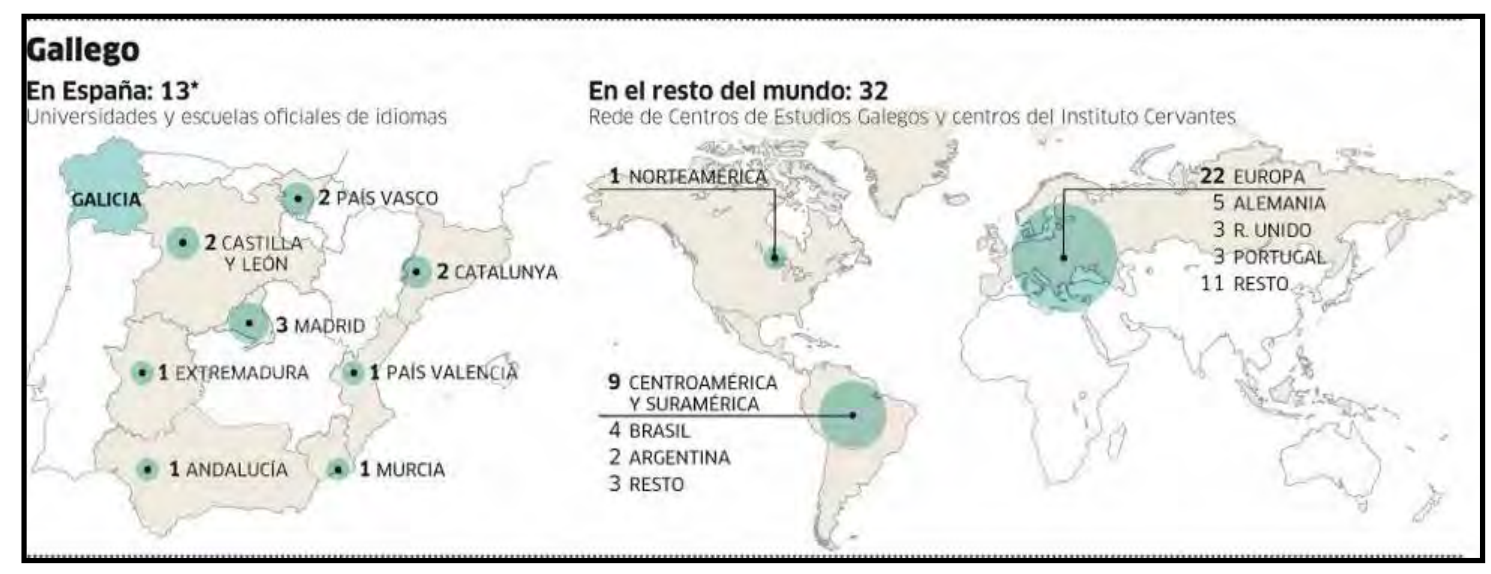

Fig. 3: Mapa de lectorados e CEG. Fonte: Diario Público, 21/02/2011

Aínda coas últimas reducións, é xusto recoñecer que esta rede de centros de ensino e difusión da cultura galega no mundo supón un avance extraordinario respecto da situación de hai un cuarto de século. Ora ben, hai problemas que cómpre poñer enriba da mesa para intentar que o enorme esforzo, en termos económicos e persoais, sexa máis rendible para a proxección exterior da lingua galega, cun bo retorno de resultados. Sinalaremos só os catro que consideramos fundamentais:

a) O sistema creado dende a Xunta carece dunha planificación previa. A rede de lectorados vaise creando por agregación de unidades creadas a proposta de académicos do exterior, aproveitando oportunidades que permiten un financiamento dos «centros de galego». Esta falta de planificación ten como resultado a dificultade de accións en rede e a execución de programas comúns, ademais do feito de que haxa áreas xeográficas sobreatendidas, con varios centros por país, incluso en poboacións pequenas, e outras áreas estratéxicas completamente descubertas.

b) A inserción dos lectorados e CEG nas universidades, co pagamento do profesorado correspondente, non leva aparellada a inclusión das materias de lingua galega no currículo académico de forma adecuada e estable. Non se planifica en coordinación co departamento responsable da política universitaria na Xunta de Galicia nin cos que, no seo das universidades correspondentes, teñen competencia no deseño curricular. Isto lévanos a unha posición de marxinalidade nos currículos académicos estranxeiros (ou a unha posición extracurricular) e á falta de acordos de reciprocidade.

c) Os investimentos da SXPL nos CEG e os obxectivos perseguibles a través deles son independentes da política interior e exterior (económica, cultural, científica...). Se comparamos o sistema galego cos sistemas vasco e catalán (por non ir máis lonxe), obsérvase que nestes as accións 
CAstro, O. / M. LiÑEIRA (eds.) (2015): Trama e urda. Contribucións multidisciplinares desde os estudos galegos, Santiago de Compostela, Consello da Cultura Galega. doi:10.17075/tucmeg.2015.

relacionadas coa lingua converxen doadamente coas de promoción da cultura, internacionalización de artistas e empresas culturais, axudas á tradución, etc. Obviamente, é máis fácil que estas linguas obteñan máis retornos económicos, turísticos, culturais...

d) A falta dunha estrutura administrativa que programe, coordine e facilite a acción exterior tamén dificulta manter puntos de referencia propios, e en definitiva complica obter beneficios dunha eventual colaboración entre institucións análogas doutros países e rexións, coordinar políticas conxuntas, etc. A promoción exterior da lingua e cultura galegas reséntese de que en Galicia non haxa un interlocutor equivalente do Instituto Camões portugués, do Etxepare vasco, do Ramon Llull catalán, do Cervantes español, etc.

Non podemos rematar este apartado de estudo do galego fóra de Galicia no ámbito universitario sen mencionar que a UNED ofrece materias de lingua e literatura galegas en tres niveis sucesivos, dentro do plan de estudos de Filoloxía Hispánica. De acordo cos programas publicados na súa web, prevese o ensino da lingua a persoas que non son falantes nativas/os, con niveis equiparables aos CELGA correspondentes. ${ }^{22}$

\subsection{O ensino do galego como lingua estranxeira en Galicia}

Se nos centramos na oferta de galego como lingua estranxeira dentro de Galicia, cómpre recoñecer que temos un notable déficit, pois a oferta é moi limitada e nada diversificada. Ata onde puidemos recadar, limítase a: (a) cursos non regrados ou sen planificación temporal fixa e segura (por tanto marxinais), coma os que o SNL universitario programou para «non galegofalantes» ou os que se ofrece a alumnado universitario con bolsa Erasmus; (b) cursos de verán para persoas estranxeiras, que se ofrecen por convenios entre as universidades galegas e a SXPL; (c) programas de voluntariado lingüístico.

O programa Volangteer é un proxecto piloto para a aprendizaxe do galego destinado a persoas estranxeiras, que se basea no acompañamento lingüístico por parte de voluntariado. ${ }^{23}$ Impúlsao a SXPL, no marco da promoción das linguas rexionais europeas, e conta coa colaboración da Universidade de Santiago de Compostela, que o ofrece a través do seu portal internacional, como unha opción para o estudantado estranxeiro do programa Erasmus e para quen teña interese no intercambio cultural.

\footnotetext{
${ }^{22}$ Para máis información, véxase: http://www.uned.es/fac-filg-hisp/

${ }^{23}$ Para máis información, véxase http://www.xunta.es/linguagalega/volangteer
} 
CAstro, O. / M. LiÑEIRA (eds.) (2015): Trama e urda. Contribucións multidisciplinares desde os estudos galegos, Santiago de Compostela, Consello da Cultura Galega. doi:10.17075/tucmeg.2015.

Os datos que analizaremos a seguir proceden todos do curso de verán decano, o organizado en Santiago de Compostela pola Real Academia Galega e o Instituto da Lingua Galega, con subvención da SXPL, que en 2012 chegou ao cuarto de século ininterrompido, cun total de arredor de 2500 alumnos e alumnas diferentes nestes anos. Para a correcta comprensión dos mapas cómpre ter en conta que recollen só datos dos últimos 5 anos e que cada punto no mapa representa un centro universitario de procedencia, polo tanto unha ou máis persoas.

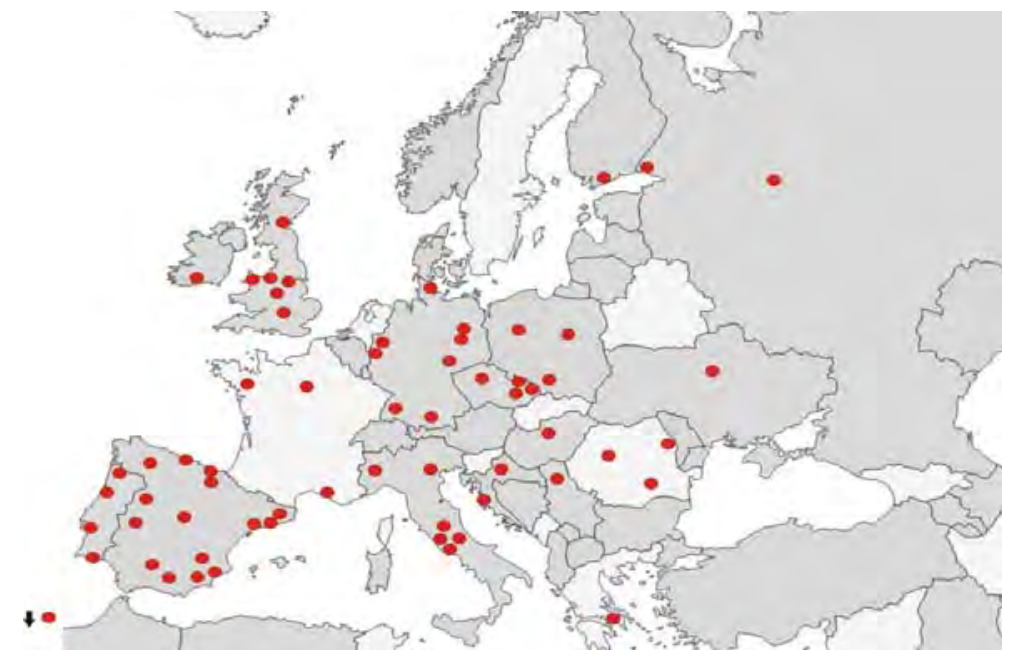

Fig. 4. Centros de procedencia dos alumnos dos cursos de estranxeiros, Santiago de Compostela (2008-2012): Europa

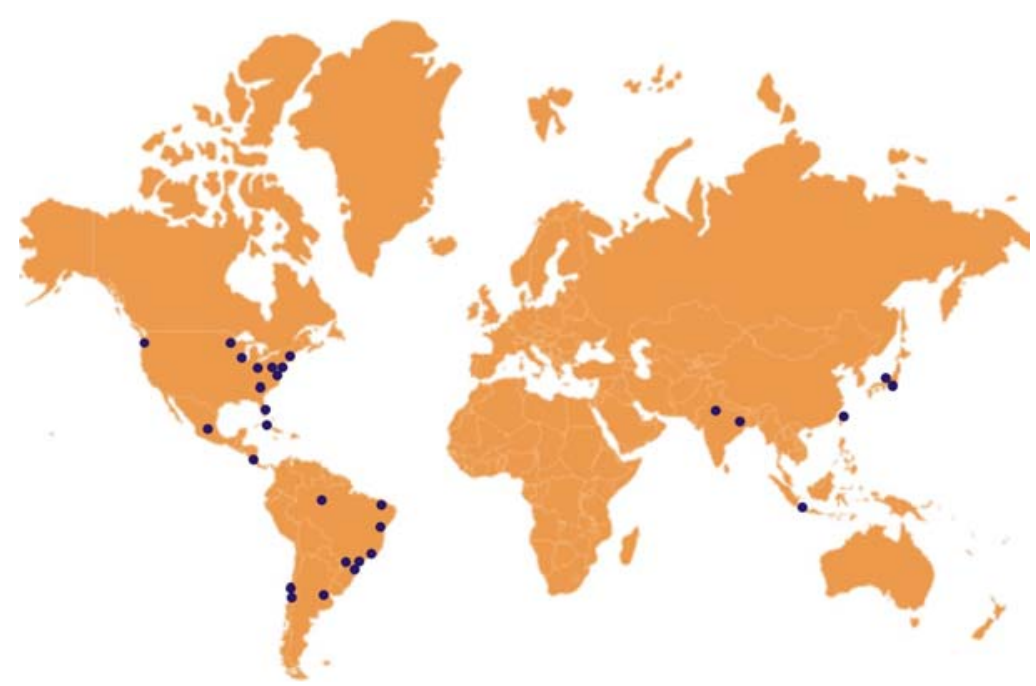

Fig. 5. Centros de procedencia dos alumnos dos cursos de estranxeiros, Santiago de Compostela (2008-2012): resto do mundo 
As características destes alumnos e alumnas dannos os seguintes perfís, interesantes para coñecermos as motivacións que os moven a achegarse a nós e podermos implementar esta vía de proxección:

a) Son minoría os alumnos e alumnas quen teñen antecedentes ou lazos familiares galegos. A maior parte dos oriúndos de Galicia son fillas/os ou netas/os da emigración peninsular ou americana. $\mathrm{O}$ reforzamento dos vínculos identitarios, a través do mantemento e coñecemento da lingua e cultura familiares de orixe, é sen dúbida unha vía que as galegas e galegos debemos aproveitar en determinadas áreas que xa se mostran propicias, e tamén un camiño a explorar noutras de emigración máis recente; ora ben, a maior parte do alumnado ten outras motivacións.

b) Hai unha relación evidente coa localización dos CEG, sobre todo porque estes reciben puntual información da convocatoria destes cursos e son interpelados para facer propostas, que ademais son avaliadas con certa prioridade. A táboa seguinte mostra o número de asistentes aos cursos por países e continentes, correlacionado coa existencia da oferta docente da Xunta de Galicia, coloreando os países en que hai ou houbo lectorado, cátedra ou CEG. Facemos notar que nalgúns casos a coincidencia dun CEG no país non é en absoluto determinante, pois non é pouco o alumnado que non vén a través deles. A modo ilustrativo, quen acode desde Cataluña procede tamén da Universitat Pompeu Fabra de Barcelona ou doutras universidades catalás como a de Vic ou Tarragona, nos tres casos centros educativos que non teñen CEG; o alumnado brasileiro procede tamén de Fortaleza, Londrina e Manaus, que tampouco teñen CEG; e chega máis alumnado portugués de Braga, Aveiro e Faro que de Lisboa, malia ser nesta última localidade onde se localiza o CEG. Hai bastante coincidencia en América, pero é difícil saber se este é un factor determinante ou se debe á presión da diáspora galega; chaman a atención en sentido contrario o leste europeo e Asia, máis particularmente o Xapón. ${ }^{24}$ Nos extremos, negando as expectativas creadas pola relación $\mathrm{CEG} /$ escolla do galego, atopamos Romanía (sen centro, 17 asistentes) e Uruguai (con cero asistentes e centro en Montevideo ata hai ben pouco tempo).

\footnotetext{
${ }^{24} \mathrm{O}$ interese polo galego semella inseparable do entusiasmo e dos recursos creados polo lingüista Take Kazu Asaka, tradutor de Rosalía de Castro ao xaponés e autor de diversos traballos de lingüística galega, entre eles unha Gramática galega, un Manual de conversa en galego e un Vocabulario básico galego, todos concibidos para público xaponés.
} 


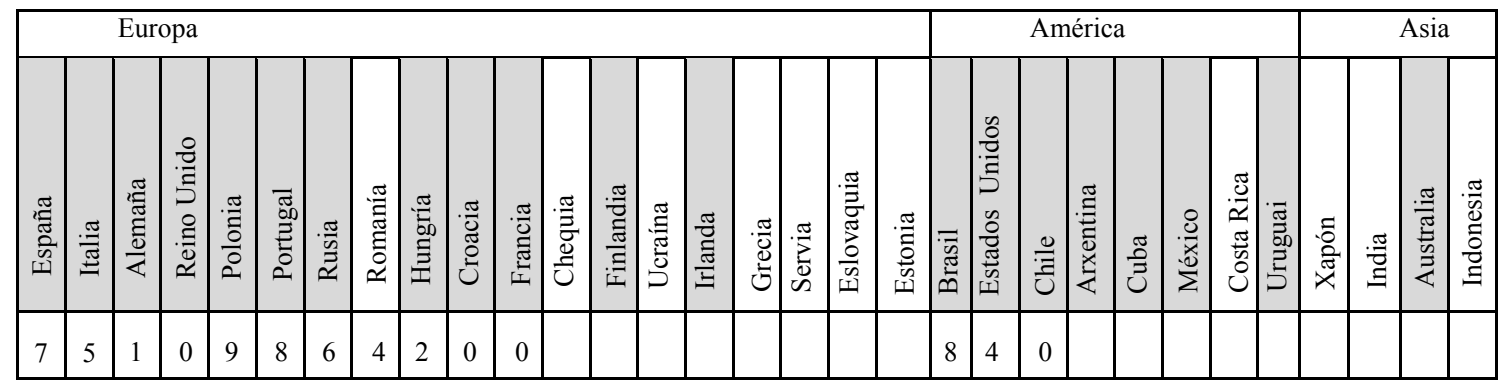

Fig. 6. Frecuencia de alumnos por países. Relación coa existencia de CEG

c) Hai alumnado estranxeiro de distintas procedencias que vén de centros universitarios de fóra dos seus países de orixe. Aquí destacan os e as participantes que traballan en universidades portuguesas ou forman parte do cadro de portugués de departamentos de hispánicas en distintas universidades (no cadro figuran atribuídos ao centro de procedencia, non por nacionalidade: Marrocos, Perú, Venezuela, Kazakhstan, etc.). Xa que logo, o interese polo galego desde o ámbito da lingüística e filoloxía portuguesas, sobre todo en Brasil e universidades estranxeiras, é unha novidade e un camiño que debemos facilitar. Noutros casos trátase de docentes, tradutoras/es e persoal investigador especializado no campo da hispanística ou da romanística, que contribúen a colocar o galego no abano de variedades lingüísticas consideradas na docencia e investigación. E noutros máis, en fin, trátase de persoal investigador e/ou falantes de linguas con historia e situación sociolingüística que garda similitudes coa do galego (polaco, bengalí...), co que queren establecer termos de comparación.

d) Existe tamén alumnado estranxeiro convocado polas características típicas (un tanto mitificadas) de Galicia e a cultura galegas: autenticidade e mantemento das tradicións, pervivencia do mundo medieval, contacto coa natureza e medio conservado, calidade dos produtos alimenticios e gastronomía, música e folclore, ruralidade e distribución en hábitat non masificado, hospitalidade e facilidade para as relacións humanas, etc.

A experiencia acumulada nos 25 anos de existencia de cursos de galego para persoas estranxeiras en Galicia mostra que esta é unha acción que dá excelentes resultados, a curto, medio e longo prazo. Referímonos con frecuencia a estas alumnas e alumnos como «a forza que vén de lonxe» e como «embaixadoras/es da lingua galega» no mundo. Sono, de feito. Destacamos algúns aspectos de interese, con só algúns trazos facilmente comprobables:

- Formación dun número considerable de especialistas coñecedoras/es da lingua galega, entre os que destacamos profesores e profesoras en distintas universidades do mundo. Moitas das persoas que se 
fixeron responsables da dirección destes centros nas súas universidades foron antigos alumnos/as dos cursos de verán. Actualmente, é significativa a cifra destas persoas que xa están participando dalgunha forma nas actividades docentes dos CEG.

- Se repasamos a nómina de investigadoras e investigadores que incorporaron o galego ao seu obxecto de estudo (lingüística, filoloxía, literatura, sociolingüística...) en diversas universidades do mundo, comprobaremos que moitas/os deles asisten ou asistiron a estes cursos. $\mathrm{O}$ mesmo ocorre cos traballos de descrición e divulgación da lingua, literatura e cultura galegas nos seus países.

- A súa contribución é especialmente significativa no campo da tradución de literatura galega a outras linguas.

\section{DIFICULTADES NO ENSINO DO GALEGO COMO LINGUA ESTRANXEIRA}

Ao longo deste capítulo exploramos a posición e valor estratéxico do galego desde a perspectiva da mundialización. Con este obxectivo analizamos a política lingüística exterior do galego, abranguendo tanto o seu ensino no ámbito universitario, primario e secundario de fóra de Galicia, como o ensino do galego como lingua estranxeira en Galicia. Sexa a través dos cursos para estranxeiros que se programan en Galicia, sexa a través dos lectorados e CEG espallados polo mundo, hai consenso en que esta é unha aposta de proveito, na que interesa investir esforzos persoais e recursos económicos. E mesmo así, por problemas estruturais e materiais aínda non resoltos, as dificultades seguen a ser moitas.

Cómpre deseñar accións que melloren a situación deste tipo específico de ensino da lingua, tanto na ampliación da oferta (temporal e curricular) coma nas condicións do ensino e aprendizaxe. Recollemos non só as nosas apreciacións persoais senón a voz, en distintos foros, de persoas que teñen a experiencia de traballar en lectorados, case sempre en condicións precarias. Precisamos, cando menos:

- Profesorado especializado, formado en ensino de segunda lingua/ en aprendizaxe do galego como lingua estranxeira.

- Materiais específicos, concibidos e elaborados de forma especializada para o ensino do galego a non falantes, na medida do posible tendo en conta a lingua ou linguas de partida (linguas de orixe ou linguas de coñecemento xeral). 
CAstro, O. / M. LiñEIRA (eds.) (2015): Trama e urda. Contribucións multidisciplinares desde os estudos galegos, Santiago de Compostela, Consello da Cultura Galega. doi:10.17075/tucmeg.2015.

- Políticas de formación continua para docentes/animadores culturais que traballan no ámbito doutras linguas e culturas.

- Materiais audiovisuais adecuados, concibidos para esta función, co fin de complementar as aulas.

- Programación de actividades de difusión cultural atractivas, que poidan itinerar.

Non todas as accións dependen de instancias públicas, polo que facemos un chamamento, unha vez máis, ao traballo cooperativo, á construción colectiva. Esa é tamén a nosa forza.

\section{REFERENCIAS BIBLIOGRÁFICAS}

CALVET, Louis-Jean (2004): Por unha ecoloxía das linguas do mundo. Trad. Alfredo Iglesias Diéguez, Santiago de Compostela, Laiovento.

DE SWAAN, Abram (1993): «The emergent world language system: An introduction», International Political Science Review, 14:3, 219-226.

DE SWAAN, Abram (2001): Words of the world: The global language system, Cambridge, Polity Press.

LEWIS, M. Paul / Gary F. Simons / Charles D. Fennig (eds.) (2013): Ethnologue: Languages of the World, Dallas, Texas, SIL International (ethnologue.com).

EUROBARÓMETRO 2006 = Eurobarómetro especial 243. "Los europeos y sus lenguas». Resumen. Comisión Europea - Representación en España (http://ec.europa.eu/spain/pdf/eurobar_lenguas_es.pdf).

EUROBARÓMETRO 2012 = Special Eurobarometer 386. "Europeans and their Languages». Report. European Commission (http://ec.europa.eu/public_opinion/archives/ebs/ebs_386_en.pdf).

FARACO, Carlos Alberto (2010): «A encruzilhada da lusofonia», Grial, 187, 76-81.

FISHMAN, Joshua A. (2001): «El nuevo orden lingüístico», Digit.HVM 3 (http://www.uoc.edu/humfil/articles/esp/fishman/fishman_imp.html).

FLAD (2008) = Promoção da Língua Portuguesa no Mund̄o. Reunião de Trabalho realizada na Fundação Luso-Americana em 5 de Novembro de 2007, Lisboa, Fundação Luso-Americana para o Desenvolvimento. (http:// www.flad.pt/ documentos/1216226048S9qMG0he4Yh87DC6.pdf).

GARCÍA MATEO, Carmen / Montserrat Arza Rodríguez (2012): The Galician language in the Digital Age / O idioma galego na era dixital, Berlin / Heildelberg, Springer.

GARRIDO, Joaquín (2010): «Lengua y globalización: inglés global y español pluricéntrico», Historia y Comunicación Social, 15, 51-66.

GÓMEZ GUINOVART, Xavier (2003): «A lingua galega en Internet», en Ana Bringas / Belén Martín (eds.), Nacionalismo e gobalización: lingua, cultura e identidade, Vigo, Servicio de Publicacións da Universidade de Vigo, 71-88.

GONZÁLEZ GONZÁLEZ, Manuel (2005): «La proyección exterior de la lengua gallega», en El español en el mundo. Anuario del Instituto Cervantes 2005. 
CAstro, O. / M. LiÑEIRA (eds.) (2015): Trama e urda. Contribucións multidisciplinares desde os estudos galegos, Santiago de Compostela, Consello da Cultura Galega. doi:10.17075/tucmeg.2015.

Madrid: Centro Virtual Cervantes (http://cvc.cervantes.es/lengua/anuario/ -anuario_05/gonzalez/p04.htm).

GONZÁLEZ GONZÁLEZ, Manuel (2007): «O ensino do galego como lingua estranxeira», Enciclopedia del español en el mundo Anuario del Instituto Cervantes 2006-2007. Centro Virtual Cervantes, 389-397

(http://cvc.cervantes.es/lengua/anuario/anuario_06-07/pdfcooficiales_02.pdf).

MORENO CABRERA, Juan Carlos (2003): El Universo de las lenguas. Clasificación, denominación, situación, tipología, historia y bibliografí, Madrid, Castalia.

OBSERVATORIO DA CULTURA GALEGA (2012): Promoción exterior do galego. Análise comparativa co catalán e o éuscaro, Santiago de Compostela, Consello da Cultura Galega (inédito).

REIS, Carlos (coord.) / Ana Paula Laborinho / Isabel Leiria / Mário Filipe / Fátima Pinheiro (2010): A Internacionalização da Língua Portuguesa. Para uma política articulada de promoção e difusão, Lisboa, Gabinete de Estatísticas e Planeamento da Educação. (http://www.gepe.min-edu.pt/np4).

\section{WEBGRAFÍA [POR ORDE DE APARICIÓN] [ÚLTIMA CONSULTA: MAIO, 2015]}

http://www.eurocom-frankfurt.de

http://www.unilat.org/SG/es

http://epp.eurostat.ec.europa.eu/statistics_explained/index.php/Foreign_language_learni ng_statistics

http://www.realacademiagalega.org/datos-uso

http://www.xunta.es/linguagalega/volangteer

http://www.xunta.es/linguagalega/o_galego_na_union_europea

http://consellodacultura.gal/mediateca/extras/galicia25anos.pdf

http://www.xunta.es/linguagalega/arquivos/cursos_exterior.pdf

http://ianasagasti.blogs.com/mi_blog/2007/03/el_instituto_ce.html

http://www.xunta.es/linguagalega/arquivos/CursosGalego-2012-2013Calendario.pdf

http://phobos.xtec.cat/galauda/

http://www.xunta.es/linguagalega/castilla_y_leon

http://www.xunta.es/linguagalega/lectorados_de_universidades

http://www.uned.es/fac-filg-hisp/ 